American Journal of Agricultural and Biological Sciences 5 (2): 161-168, 2010

ISSN 1557-4989

(C) 2010 Science Publications

\title{
An Investigation of Solutions to Empowering Iranian Rural People to Use Services Offered by Information and Communication Technology Service Offices: The Case of Isfahan Province
}

\author{
Tahmasb Maghsoudi, Mehdi Mirdamadi, Jamal Farajollah Hosseini and Mahmod Hosseini \\ Department of Agricultural Extension and Education, Islamic Azad University, \\ Science and Research Branch, Tehran, Iran
}

\begin{abstract}
Problem statement: Knowledge and information should be provided for people effectively as they can use it in their life. Empowering rural people to use formation and knowledge is necessary and important than its Transfer. In order to develop information and communication services in rural area, services offices have been established, but the villagers do not ability to use services. This research identified the empowerment solutions for rural people in order to use services offered by ICT Services offices. Currently have access to $67 \%$ Iranian rural populations assess ICT Service Offices, therefore, empowering people can promote efficiency and effectiveness of ICT Service offices and accelerate rural development. Approach: A descriptive methodology was applied in this study, through questionnaires. In this study, 210 local authorities in five counties (Fereydan, Fereydonshahr, Semirom, Natanz and Golpaygan) of Isfahan province were selected through random sampling. The statistical analysis after data extraction was carried out by SPSS version13.0. Factor analysis was used for data analysis. Results: The findings revealed that four factors containing 33 variables explained $70.9 \%$ of variance. These factors were named: awareness (27.86\% variance), Facilitation $(16.39 \%$ variance), an institutional (13.55\% variance) and context building (12.18\% variance) to the representation. Conclusion: The findings regarding the strategies used in order to empower villagers desirable services shows that in short-term order should take action to capitalize on fundamental measures, facilitative and increase access to education and services and will encourage local orientation. Among the long-term should also focus on Facilitation-Increasing access to education and to encourage the local orientation, and using basic measures were. In order to empower the villagers regard to awareness factors-communication, facilitative-motivational, institutional-Migration and property should be of great concern, that the awareness factor that emphasis on cognitive and communication will be more important.
\end{abstract}

Key words: Empowerment, rural ICT Services Offices (ICTSO), Iran, factor analysis

\section{INTRODUCTION}

Something that causes a great and wise nation is based, is training to all its people and spread to influence people (Semen Nap, 1900) and quoted Gandhi "independence of the low and lower to begin, if each village self-sufficient and be able to manage its independence is obtained Affairs. Knowledge, awareness and information for people to opportunities and challenges in response to social changes, economic and technology are required. But that is useful and beneficial; such knowledge should be effectively brought to the people so they can use this information and knowledge of their life. More than 850 million people in developing countries have been away a wide range of information, knowledge and awareness (Bastian and Bastian 1996). ICT allows countries to modernize the system, increase production and enable this country to move faster to economic development (Uppal, 2005).

Any success in rural development depends on update information, reliable and sufficient information that the role of ICTs in achieving it is very important. ICTs can Power to rural communities and Awarded to and conditions for being involved in the development process can provide. With new ICTs, rural communities can improve the ability and progress of his life Obtained conditions through education and discussion,

Corresponding Author: Tahmaseb Maghsoudi, Department of Agricultural Extension and Education, Islamic Azad University, Science and Research Branch, Tehran, Iran 
with others to a surface, the motivation for their participation in the fate of reach (Chapman and Slaymaker, 2002).

In Iran, ICT services are provided jointly by ICT Ministry, other ministries (agricultural ministry and some other organizations in public, private and cooperative sectors. According to official reports, 8400 rural ICT Service Offices (ICTSO) have been opened by now, covering 12 million people in the rural area, which accounts for $75 \%$ of the total target population These offices provide Internet connection, government public services, financial and postal services (Islamic Republic of Iran ICT Ministry, 2009).

ICTs have high potentials to improve the outlook for market, empower rural communities target marginal groups and create jobs (Pringle and David, 2002). In this respect, empowerment of people to use ICT services could increase the effectiveness of ICT SO and contribute to rural development this study aims at identifying rural empowerment solutions in order to improve the use of services of ICT SO by rural people. Three following stages have been set in Iran, to increase ICT usage in rural ICT awareness and inclination to use them: At this stage, ICT attractions and potentials are introduced to rural people and they encouraged using ICT.

Effective use: Appropriate strategies and solutions are followed at this stage, to make an effective use of ICT in villages.

Active participation and contribution: Rural people are empowered and encouraged to develop the content of ICT (Islamic Republic of Iran ICT Ministry, 2001).

This study focuses on the second stage and aims to find practical solutions to better use of ICT services offered by ICTSO.

Many efforts by the various experts have had to provide operational definition of empowerment. Conger and Kanungo (1988) concept of empowerment mean in the concepts of control and power Thomas and Velthouse (1990) provide the means to grant authority (Munyua, 2002), Finally, the main approach can be introduced in the empowerment, which include communication, motivation and cognitive approach is can be identified; The communicative approach with the aim enabling and to help power distribution strategy, Motivational approach with the aim of enabling and to choose the right strategy to help increase confidence if accepted And finally cognitive approach aimed to increase internal motivation tasks and strategies to aid impact, competency, meaning and choices is operation (Conger and Kanungo, 1988).
Empowerment can be considered a process in which people overcome the barriers to progress, are doing activities that cause their master is their determination. Enabling or empowerment means to overcome inequalities of the foundation so Selfsufficiency is different. beside, this term means to exercise power rather than the others, the description is in power can do something that shows a person (enabling) and requires strategies to encourage use of other forms of influence no Mandatory this perspective, between enabling and authority, there are fundamental differences (Pringle and David, 2002).

Empower villagers to profit from the services provided by rural ICT, including ICT development policies proposed requirements are approaches that should communication means is the cognitive and motivational. Since the nature and activities of rural areas have special concerns are three approaches above, you approach the three the time evaluate.

Today, between stimulus and context factors maker action plans for sustainable development of rural factor perception, understanding and awareness of rural residents and environment of their skills and learning words, rules of individual behavior in the life of intellectual, social and professional attention and the majority consensus experts and those involved in rural planning and development has been. Therefore, study the existing literature and texts can often receive new paradigms importance of sustainable development of rural education based on empowerment of villagers and rural people to access the information resources and strategy emphasizes not suitable for this purpose also, extension approaches-Information were expressed, the different dimensions of content, educational programs, channels communications, the costs and services is considered.

Research shows that if the information service, trading services and government services (interactive), the use of ICT inappropriate content limit these services (Dossani and Misra, 2005). Another approach lack of access, low service quality, dependence on service work activity level and size and cost farmers obtain services from serious limitations in the use of ICT is empowerment (Warren, 2005). Strategies considered in this study were as follows:

- Analysis of individual levels of ICT must be studied with interactive access to three elements, skills and status of individual and farmer motivations done

- Can see areas should be focused and continuity

- Major applications software and hardware information and application is the next priority 
The overview of rural ICT projects to create effective organizational mechanisms, efforts to coordinate production and distribution of educational resources used to promote the empowerment of rural cases knows (Uppal, 2005). Study of ICT use in rural communities, including success factors increase the skills capacity, public access and provide appropriate local content obtained two first factor than other factors in priority and importance, have the capabilities and capacity of rural communities for increased public access (Seeverse, 1997). Using ICTs programs by farmers and utilizing specialized needs, planning and background to provide necessary environmental conditions with emphasis on the person will be beneficiary (Thomas and Velthouse, 1990). For rural ICT success, various elements of social awareness, capacity building, public access and content to provide local needs is considered essential (Girard, 2003). That efficiency of ICT is depends environmental, technical, human, social-economic and geographical condition (Chand et al., 2005). Such as empowerment strategies to create awareness about the facilities and opportunities that ICT can developing countries and to create, facilitate the use of ICT through the communication centers and the necessary changes in the program languages and cultures in different countries development, should be followed (Bastian and Bastian, 1996). For design ICT program services in the rural areas attention in five branches of information services, capacity building, sustainability, technology and policy planning is important (Opena, 2004). According to the literature, communicative, cognitive and motivational approaches should be adopted, in order to empower villagers to use ICTs. Various aspects of empowerment have been shown in Fig. 1.

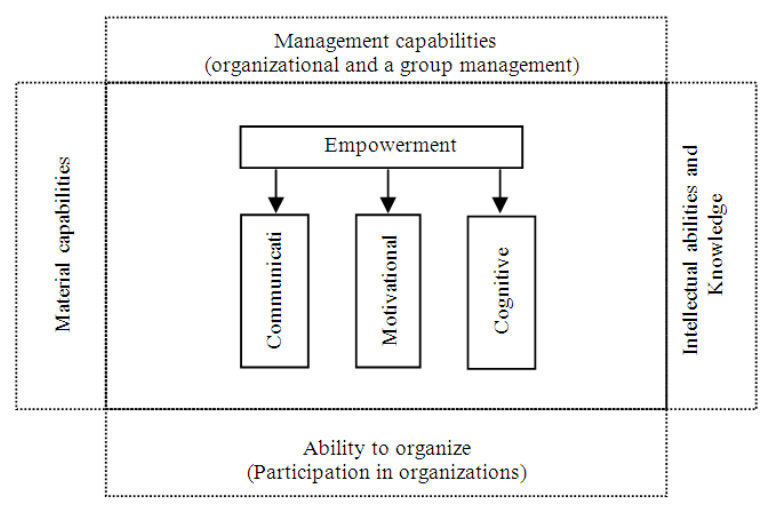

Fig. 1: Essential elements of rural empowerment approach in using ICT services in rural
The main purpose of this study was the identification of solutions to empowering Iranian rural people to use ICT Service Offices. With this purpose in mind, the following objectives were compiled:

- Investigation of rural people awareness in use ICT service office

- Suitable content for rural people empowerment

- Identification of solutions to empowerment to use ICT service office

\section{MATERIALS AND METHODS}

The methodology of this study was descriptive and it was carried out as a survey. The instrument that was used for data collection was a questionnaire. The statistical population is responsible institutions local villages in Isfahan province, in the study of random sampling is used. This study was conducted in Isfahan province with the total 454 are rural ICT Service offices. First five random city Friedan, Fereidonshar, Semirom, Golpayegan, Natanz and was total of 454 villages in this era place and in this five city ICT Service offices is 122. Using the formula Kokran 210 people were estimated sample size. Cochran formula. Thus, in a pre-test, 30 questionnaires were distributed and the variance of the dependent variable (empowerment) was calculated as $\mathrm{S}^{2}=0.42$ Using $\mathrm{N}=$ $978, d=0.05$ and $t=1.96$, the required sample size was determined to be 172 persons; to increase certainty; it was increased to 210 persons (Table 1). The research sampling method was stratified:

$$
\mathrm{n}=\frac{\mathrm{N}(\mathrm{t} . \mathrm{s})^{2}}{\mathrm{Nd}^{2}+(\mathrm{t} . \mathrm{s})^{2}}, \mathrm{n}=210
$$

Validity of the method for determining content validity was used to determine the validity of subject specialists and experts have been used. Cranach's Alpha method to calculate the coordination with the aim Cranach's Alpha internal reliability evaluation questionnaires and by utilizing that the amount of 0.71 were the reliability coefficients are good. In order to analyze data collected from SPSS13 software was used. Data for the study of R type factor analysis has been used.

\begin{tabular}{lccc}
\multicolumn{4}{l}{ Table 1: Number of chosen local authorities on selected county } \\
\hline County & $\begin{array}{c}\text { Number of } \\
\text { village }\end{array}$ & $\begin{array}{c}\text { Total number of } \\
\text { local authorities }\end{array}$ & $\begin{array}{c}\text { Number of } \\
\text { chosen }\end{array}$ \\
\hline Frieden & 103 & 257 & 60 \\
Fereidonshar & 93 & 165 & 35 \\
Semirom & 103 & 277 & 58 \\
Golpayegan & 83 & 150 & 27 \\
Natanz & 72 & 129 & 30 \\
Total & 454 & 978 & 210
\end{tabular}




\section{RESULTS}

Personal characteristics: The results of this study showed that Average age of the respondents was about 37 (36.83) and the average year of their membership in rural organizations was about 7 (6.83). About 39\% (38.6) of the respondents had a high school diploma and about 24\% (24.3) of them had a B.Sc. degree. Most of the respondents $(76.7 \%)$ were male

Respondent's awareness to ICTSO: One of the variables studied, cognitive dimensions and conditions of respondents wish their skills to rural services offices are. Respondents attitude evaluate Comment to rural ICTs service offices set of questions to determine the cognitive dimensions, willingness and skills of service utilization has offices. The results show that the awareness main purposes, assistance from others using the service offices and agencies awareness with procedures established are the highest priority and service delivery in optimal form and needs the desired rate by offices are the lowest priority (Table 2 ).

Contents preferred by respondents: As showed in Table 3, "ICTSO objectives, programs and services", “ benefits and advantages of ICT services to individual personas" and "benefits and advantages of using ICT services for local community" were high on the list of respondents' priorities and "the costs paid and efforts made for rural ICT" was the lowest priority.
Empowerment solutions to enable villagers to use ICT services: According to the results As showed in Table 4, respondents gave top priorities to "simultaneous investment in short-, middle-and longterm training courses", "employing local contact persons" and "start with services which are of tangible benefits to individual persons". On the other hand, "start with basic services and gradual moving toward complementary services" was the lowest priority solution.

Factor analysis in rural empowerment strategies to using ICTSO: In order to identify influential factors of empowerment were used factor analysis $\mathrm{R}$ type techniques. To ensure data suitable for factor analysis was used Kaiser-Meyer-Olkin (KMO) coefficient value equal to the 0.965 and show the suitability of data for analysis and also Bartletts test was significant. Table 5 KMO measure and Bartlett's test to assess appropriateness of the data factor analysis.

The results show that 33 variables in four factors classified in total $70.9 \%$ of the empowerment factors to explain. Factors that have Eagan value were higher than 1 are considered factors in the rotation Varimax method is used. After the rotation variables than 0.50 may have been considered. The first factor alone, $27.860 \%$ of the variance factors and agents will explain the second, third and fourth, respectively, 16.399, 13.559 and $12.188 \%$ of the variance factors to explain. Percentage of variance, Eagan values and cumulative percentage in the Table 6.

Table 2: Priority setting respondent's awareness to rural ICTs service offices

\begin{tabular}{|c|c|c|c|c|}
\hline Statements & Mean & Standard division & $\mathrm{CV}$ & Priority \\
\hline Awarded to main objectives established offices in rural communications & 1.76 & 0.773 & 0.438 & 1 \\
\hline Need to get help from others to communication needs & 1.92 & 0.871 & 0.453 & 2 \\
\hline Awarded to start the process of rural communications services offices & 1.85 & 0.853 & 0.426 & 3 \\
\hline Activities in how to use the services you need offices & 1.71 & 0.819 & 0.478 & 4 \\
\hline Awarded to in various aspects offices of rural communications services & 1.66 & 0.802 & 0.484 & 5 \\
\hline Awarded to evaluation methods, supervision and control in offices & 1.73 & 0.846 & 0.490 & 6 \\
\hline Awarded to duties of ICT offices in rural & 1.69 & 0.880 & 0.520 & 7 \\
\hline Awarded to facilities and equipment in the offices & 1.52 & 0.839 & 0.550 & 8 \\
\hline Help to others to needs for their offices, can help & 1.47 & 0.850 & 0.580 & 9 \\
\hline How much will Services offered in the offices to meet your needs & 1.51 & 0.929 & 0.616 & 10 \\
\hline How much you think the form of offices desirable activities is presented & 1.33 & 0.878 & 0.657 & 11 \\
\hline Statements & Mean & $\begin{array}{l}\text { Standard } \\
\text { division }\end{array}$ & $\mathrm{CV}$ & Priority \\
\hline ICTSO objectives, programs and services & 1.86 & 1.010 & 0.546 & 1.0 \\
\hline Benefits and advantages of ICT services to individual persons & 1.75 & 0.998 & 0.570 & 2.0 \\
\hline Benefits and advantages of using ICT services for the local community & 1.77 & 1.040 & 0.588 & 3.0 \\
\hline How to use the basic services (e.g., post, post bank, Internet and other services) & 1.70 & 1.030 & 0.606 & 4.0 \\
\hline Disadvantages of ignoring ICT services & 1.71 & 1.070 & 0.624 & 5.5 \\
\hline The costs of ICT services & 1.63 & 1.010 & 0.624 & 5.5 \\
\hline How to use e-services of ministries and governmental organizations & 1.58 & 0.995 & 0.631 & 7.0 \\
\hline Ways to access and use ICT services & 1.66 & 1.050 & 0.632 & 8.0 \\
\hline The costs paid and efforts made for rural ICT & 1.57 & 1.010 & 0.645 & 9.0 \\
\hline
\end{tabular}


Table 4: Priority in rural empowerment strategies to using ICT services offices

\begin{tabular}{|c|c|c|c|c|}
\hline Empowerment strategies & Mean & $\begin{array}{l}\text { Standard } \\
\text { division }\end{array}$ & $\mathrm{CV}$ & Priority \\
\hline Simultaneous investment in short-, middle-and long-term training & 1.81 & 0.99 & 0.545 & 1.0 \\
\hline Employing local contact persons (such as rural teachers and local extension agents) & 1.71 & 0.97 & 0.564 & 2.0 \\
\hline Start with services which are of tangible benefits to individual persons & 1.53 & 0.86 & 0.565 & 3.0 \\
\hline Holding Educational meetings in mosques and ICTSO with rural volunteers & 1.70 & 0.96 & 0.566 & 4.0 \\
\hline Introducing ICTSO goals and future Services to villagers & 1.77 & 1.01 & 0.572 & 5.0 \\
\hline Make it mandatory for all villagers to use ICT for paying for some services & 1.70 & 0.97 & 0.575 & 6.0 \\
\hline Employing local leaders to encourage villagers to use ICT services & 1.68 & 0.97 & 0.578 & 7.5 \\
\hline Start with services which are of tangible economic benefits & 1.79 & 1.04 & 0.578 & 7.5 \\
\hline reducing incorrect interpretations and applications of ICT in the village & 1.67 & 0.97 & 0.580 & 9.5 \\
\hline Explaining how easy villagers can use ICT services & 1.57 & 1.01 & 0.580 & 9.5 \\
\hline Employing local trained operators in ICTSO & 1.76 & 1.04 & 0.593 & 11.0 \\
\hline Start with low cost services & 1.77 & 1.05 & 0.594 & 12.0 \\
\hline Introducing the valuable contribution of ICT services to personal and social life & 1.65 & 0.98 & 0.597 & 14.0 \\
\hline Using radio and television & 1.76 & 1.05 & 0.597 & 14.0 \\
\hline Strengthening local institutions and using them to help people in the field of ICT & 1.60 & 0.95 & 0.597 & 14.0 \\
\hline Providing incentives to villagers who use various ICT services & 1.69 & 1.01 & 0.600 & 16.0 \\
\hline using local culture to empower & 1.65 & 1.00 & 0.602 & 17.0 \\
\hline Empowerment with emphasis on ICT services in the form one or more projects & 1.65 & 0.94 & 0.603 & 18.0 \\
\hline Holding local competitions with the subject of ICT applications & 1.52 & 0.92 & 0.604 & 19.0 \\
\hline Improving access to rural ICT & 1.68 & 1.02 & 0.607 & 20.0 \\
\hline Value adding to ICT services & 1.71 & 1.04 & 0.608 & 21.0 \\
\hline Giving villagers a sense of ownership of ICTSO & 1.68 & 1.03 & 0.611 & 22.0 \\
\hline Start with superior services & 1.50 & 1.92 & 0.617 & 23.0 \\
\hline Developing villagers' skills to use ICTs & 1.69 & 1.05 & 0.621 & 24.0 \\
\hline Start with progressive villagers and encourage them to use services & 1.71 & 1.06 & 0.622 & 25.0 \\
\hline Use of local organizations for making villagers familiar with ICT services & 1.54 & 0.96 & 0.623 & 26.0 \\
\hline Providing essential rural services through ICTSO & 1.65 & 1.05 & 0.635 & 27.0 \\
\hline $\begin{array}{l}\text { Awarded to the villagers gradually building goals established offices and } \\
\text { services offered in the offices }\end{array}$ & 1.64 & 1.05 & 0.640 & 28.0 \\
\hline $\begin{array}{l}\text { Use of written media (newspapers, magazines, brochures and the like) to } \\
\text { provide practical guidelines for using ICT services }\end{array}$ & 1.62 & 1.04 & 0.640 & 29.0 \\
\hline $\begin{array}{l}\text { Empower villagers and step by step starting from the leading groups and } \\
\text { has high potential exploitation }\end{array}$ & 1.58 & 1.02 & 0.647 & 30.0 \\
\hline Describing the way villagers can use ICT services & 1.69 & 1.10 & 0.480 & 31.0 \\
\hline Introducing ICT services which could be provided by other local institutions & 1.55 & 1.05 & 0.680 & 32.0 \\
\hline $\begin{array}{l}\text { Start with basic services (e.g., post and internet) and gradual moving toward } \\
\text { complementary services (e.g., e-learning, e-commerce and e-government) }\end{array}$ & 1.50 & 1.03 & 0.689 & 33.0 \\
\hline Obtain full service in the second step to encourage villagers to provide services using ICT in the offices & 1.62 & 1.15 & 0.711 & 34.0 \\
\hline Familiar building to obtain benefits and advantages of ICT services & 1.43 & 1.08 & 0.735 & 35.0 \\
\hline
\end{tabular}

Table 5: KMO measure and Bartletts test to assess appropriateness of the data factor analysis

Bartletst test of sphericity

\begin{tabular}{lll} 
Sig. & Approx. chi-square & KMO \\
\hline 0.000 & 6695.056 & 0.965 \\
\hline
\end{tabular}

Table 6: Number of extracted factor, Eigen values and variance explained by each factors

\begin{tabular}{llll}
\hline Factors & Eigen value & Variance $(\%)$ & $\begin{array}{l}\text { Cumulative } \\
\text { of variance }(\%)\end{array}$ \\
\hline Factor 1 & 4.408 & 27.86 & 27.86 \\
Factor 2 & 2.368 & 16.399 & 44.259 \\
Factor 3 & 1.317 & 13.559 & 57.818 \\
Factor 4 & 1.147 & 12.188 & 70.919 \\
\hline
\end{tabular}

Variables studied in each group of factors shows that the first factor as Director AwarenessCommunication $27.86 \%$ of the variance on influence factors that first step in empowerment is cognitive and awareness dimensions and emphasis in promoting the villagers of different dimensions knowledge, skills and attitude is. Variables were the operating after rotation Varimax in the Table 7.

The second factor operating in the name facilitation-Motivational named is $16.399 \%$ of variance factors will explain and point to facilitate that access and use and reduce costs by using effective service in rural area. The advantage of operating as variables local leaders, local Volunteers, reduce cost of service, emphasizing the individual benefits and the benefit of local culture has been used and that the mechanisms of ICT services offices to facilitate the empowerment villagers is effective. Variables were the operating after rotation Varimax in the Table 8.

The 3rd factor that institutional-ownership factor is named, $13.559 \%$ explained variance factors and the emphasis on strengthening local institutions and creating a sense of ownership in rural ICT offices. 
Table 7: Variables loaded in first factor using Varimax rotated factor analysis

\begin{tabular}{lll}
\hline Factor name & Variable & Factor loading \\
\hline Awareness & Introducing ICTSO goals and future services to villagers & 0.54 \\
& Awarded to the villagers gradually building goals established offices and services offered in the offices & 0.633 \\
& Describing the way villagers can use ICT services & 0.605 \\
& Developing villagers' skills to use ICTs & 0.597 \\
& Use of written media (newspapers, magazines, brochures and the like) & 0.627 \\
To provide practical guidelines for using ICT services & 0.602 \\
Using radio and television & 0.707 \\
Holding local competitions with the subject of ICT applications & 0.645 \\
Reducing incorrect interpretations and applications of ICT in the village & 0.608 \\
Providing incentives to villagers who use various ICT services & 0.617 \\
Start with progressive villagers and encourage them to use services awarded to the villagers gradually & 0.764 \\
building goals established offices and & Services offered in the offices & 0 \\
\hline
\end{tabular}

Table 8: Variables loaded in second factor using Varimax rotated factor analysis

\begin{tabular}{llc}
\hline Factor name & Variable & Factor loading \\
\hline Motivational & Start with superior services & 0.553 \\
& Start with low cost services & 0.591 \\
Employing local leaders to encourage villagers to use ICT services & 0.789 \\
& Employing local contact persons (such as rural teachers and local extension agents) & 0.784 \\
Start with services which are of tangible benefits to individual persons & 0.758 \\
& Start with basic services (e.g., post and internet) and gradual moving toward & 0.534 \\
& complementary services (e.g., e-learning, e-commerce and e-government) & 0.571 \\
& Simultaneous investment in short-, middle- and long-term training & 0.516 \\
\hline
\end{tabular}

Table 9: Variables loaded in 3rd factor using Varimax rotated factor analysis

\begin{tabular}{llc}
\hline & Variable & Factor \\
Factor name & Empower villagers and step by step starting from the leading groups and has high potential exploitation & 0.514 \\
\hline Institutional & Start with superior services & 0.634 \\
& Strengthening local institutions and using them to help People in the field of ICT & 0.585 \\
& Start with services which are of tangible economic benefits & 0.765 \\
& Make it mandatory for all villagers to use ICT for paying for some & 0.648 \\
& Services (e.g., electricity, telephone, healthy water & 0.923 \\
& Giving villagers a sense of ownership of ICTSO & 0.661 \\
\hline & Value adding to ICT services & Factor loading \\
\hline & & 0.650 \\
Table 10: Variables loaded in 4th factor using Varimax rotated factor analysis & 0.591 \\
\hline Factor name & Variable & 0.732 \\
\hline Context building & Employing local trained operators in ICTSO & 0.743 \\
& Introducing the valuable contribution of ICT services to personal and social life & 0.755 \\
& Introducing ICT services which could be provided by other local institutions & 0.734 \\
Improving access to rural ICT & 0.744 \\
\hline
\end{tabular}

Variables in this factor is creating a sense of ownership, create value, strengthen and empower local institutions and starting from the leading group has been. Variables were the operating after rotation Varimax in the Table 9.

The 4th factor to the agent named context building $12.188 \%$ of the variance factors empowerment was explain. Variables in this factor are ease of use for context building, application services, full service and definition obtained Services have been. Variables were the operating after rotation Varimax in the Table 10.

\section{CONCLUSION}

Research findings regarding the strategies used to empower villagers in the short term action should be investment on fundamental plan, facilitation and increased access to education services and will encourage decentralization. Among the long-term focus should also facilitator, increased access and education. For empowerment should be as much as possible like the methods to create a sense of ownership of offices, a 
valuable painting of rural ICT, emphasizing the benefits of services, awareness with methods of obtaining services, obtain full service and second step to encourage use, using multimedia and concentrated methods such as holding local competitions with the subject use and application of ICT, use of local organizations, defined Services that other institutions in the context of local ICT can be deliver, empowerment with emphasis on particular ICT services in the form of One or more projects to compulsory process for using ICT to avoid special services.

Research findings regarding the content to be presented, should focus on the personal benefits and advantages described the use of ICTs services, office services described, the benefits of service for the local community and disadvantage done due to lack of use. Cases such as how to use the ministries service and governmental organizations and private e-services, access and use of ICT, explain costs and the status of costs for services accepted by the government, not as the content of awareness messages is considered. Empower villagers to the awareness-communication factor, facilitator-Motivational, institutional-ownership and context building should be considered fact, the awareness factor that emphasize cognitive and communication dimension will be more important.

Recommendations: In order to empower rural people to use services of ICTSO, the following suggestions have been provided based on the research findings Introducing the benefits and advantages of ICT services to rural individual persons and rural community:

- Increased after the cognitive approach of villagers to improve the attitude in using ICT services Emphasis should be put on easy and equal access to services, localism and capacity buildingParticipatory approaches should be adopted, instead of up-down approaches

- More cooperation among local institutions and organizations (e.g., agricultural cooperatives, farmers' organizations) with ICTSO, could institutionalize ICTSO services and give a sense of ownership to villagers

Three major changes in procedures, responsibilities and learning should be paid attention in empowerment models

- Providing incentives (e.g., free services, tours and educational course) for villagers to encourage them to use ICT services

- Content to be presented in order to increase rural people empowerment should include a description of rural ICTs offices objectives, programs, benefits and advantages described service offices, how to use the post bank services and Internet and describe costs of services in this office

- In order to empowering rural people to use of ICT services offices need to process the following steps:

Step 1: A gradual identification towards goals, methods and orientation services obtained the benefit and advantages of using ICT services offices

Step 2: Facility and motivate the use of services by reducing cost, quality of service and cooperation with leading groups are

Step 3: Strengthening local institutions and transferring ownership and decision-making power and emphasis to the services that rural interests have economical benefits

Step 4: Increased access to ICT services and making tangible everyday is rural. For this purpose, full service presentation applied making tangible role and value of building services using trained operators to next steps in using empowerment of rural ICT services are

\section{REFERENCES}

Bastian, S. and N. Bastian, 1996. Assessing Participation: A Debate from South Asia. Konark Publishers, New Delhi, ISBN: 8122004598, pp: 288.

Chand, A.A., D. Leeming, E. Stork, A. Agassi and R. Biliki, 2005. The impact of ICT on rural development in Solomon Islands: The PFNET Case. ICT Capacity Building at USP Project, The University of the South Pacific. http://www.usp.ac.fj/jica/ict_research/documents/pd f_files/pfnet_report.pdf

Chapman, R. and T. Slaymaker, 2002. ICTs and rural development: Review of the literature, current interventions and opportunities for action. Overseas Development Institute (ODI). http://www.kubatana.net/html/archive/inftec/02110 1odi.asp?sector=RURDEV\&year=2002\&range_star $\mathrm{t}=1$

Conger, J.A. and R.N. Kanungo, 1988. The Empowerment process: Integrating theory and practice. Acad. Manage. Rev., 13: 471-482. http://www.jstor.org/stable/258093

Dossani, R. and R. Misra, 2005. Enabling ICT for Rural India. Stanford University, India. http://iisb.stanford.edu/pubs/20972/ICT_full_Oct05.pdf 
Girard, B., 2003. The One to Watch. Radio, New ICTs and Interactivity. Food and Agriculture Organization of the United Nations, In collaboration with The Friedrich Ebert Stiftung (FES) Geneva Office and Communication for Development Group Extension, Education and Communication Service Research, Extension and Training Division Sustainable Development Department. FAO, Rome. http://www.smallstock.info/reference/FAO/006/y47 21e/1-2-watch.pdf

Islamic Republic of Iran ICT Ministry, 2001. Introduction to ICT development strategy in Iran. ICT Study Committee, Tehran.

Islamic Republic of Iran ICT Ministry, 2009. Investigation of rural ICT situation. Statistics 2009. Munyua, H., 2002. The role of information and communication technologies for rural development and food security: Lessons from field experiences in developing countries. Ph.D. Thesis, The Technical University of British Columbia, Canada. http://www.fao.org/sd/CDdirect/CDre0055c.htm

Opena, M., 2004. Telecentre support network product and services planning. Proceeding of the Asian Workshop Outcomes, Dec. 3-3, CRDI, Chennai, pp: 1-19. http://www.crdi.ca/uploads/userS/11116067871Chennai_outcomes.pdf
Pringle, I. and M.J.R. David, 2002. Rural Community ICT applications: The Kothmale model. Elect. J. Inform. Syst. Dev. Countries, 8: 1-14. http://www.ejisdc.org/ojs2/index.php/ejisdc/article/ view/43

Seeverse, B., 1997. Education through Cooperative Extension. Delemar Publishers, USA., ISBN: 0827371721, pp: 288.

Thomas, K.W. and B.A. Velthouse, 1990. Cognitive elements of empowerment: An interpretive model of intrinsic task motivation. Acad. Manage. Rev., 15: 666-681.

Uppal, M., 2005. Lessons learned From PAN Asia Projects on ICTs in rural areas. International Development Research Center (IDRC). https://idlbnc.idrc.ca/dspace/handle/123456789/31151

Warren, M.F., 2005. International Literature Review, in Information and Communication Technologies (ICT) Awareness, Usage and Barriers: A study of Agri-Businesses in the City of Ottawa. COMPAS Inc., Ottawa. 